$\sum_{i=126 / 199}^{i 0}$

SERI/TR-62-264

September 1979

\title{
Legal Considerations in the Development and Implementation of Biomass Energy Technologies
}

Charlotte Schwab
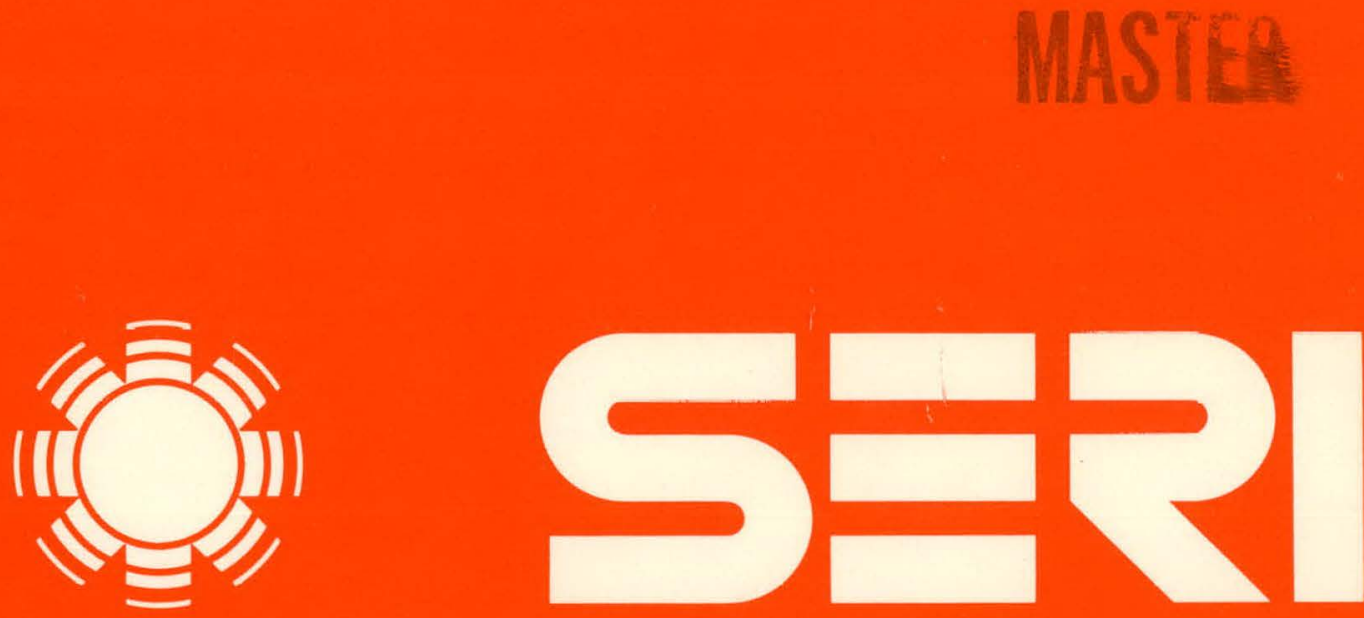

Solar Energy Research Institute

A Division of Midwest Research Institute

1536 Cole Boulevard

Golden, Colorado 80401

Operated for the

U.S. Department of Energy

under Contract No. EG-77-C-01-4042 


\section{DISCLAIMER}

This report was prepared as an account of work sponsored by an agency of the United States Government. Neither the United States Government nor any agency Thereof, nor any of their employees, makes any warranty, express or implied, or assumes any legal liability or responsibility for the accuracy, completeness, or usefulness of any information, apparatus, product, or process disclosed, or represents that its use would not infringe privately owned rights. Reference herein to any specific commercial product, process, or service by trade name, trademark, manufacturer, or otherwise does not necessarily constitute or imply its endorsement, recommendation, or favoring by the United States Government or any agency thereof. The views and opinions of authors expressed herein do not necessarily state or reflect those of the United States Government or any agency thereof. 


\section{DISCLAIMER}

Portions of this document may be illegible in electronic image products. Images are produced from the best available original document. 


\author{
Printed in the United States of America \\ Available from: \\ National Technical Information Service \\ U.S. Department of Commerce \\ 5285 Port Royal Road \\ Springfield, VA 22161 \\ Price: \\ Microfiche $\$ 3.00$ \\ Printed Copy $\$ 4.50$
}

\begin{abstract}
NOTICE
This report was prepared as an account of work sponsored by the United States Government. Neither the United States nor the United States Department of Energy, nor any of their employees, nor any of their contractors, subcontractors, or their employees, makes any warranty, express or implied, or assumes any legal liability or responsibility for the accuracy, completeness or use fulness of any information, apparatus, product or process disclosed, or represents that its use would not infringe privately owned rights.
\end{abstract}




\title{
SERI /TR- 62- 264 \\ UC CATEGORY: UC-61
}

\begin{abstract}
ENVIRONMENTAL AND INSTITUTIONAL CONSIDERATIONS IN THE DEVELOPMENT AND IMPLEMENTATION OF BIOMASS

ENERGY TECHNOLOGIES
\end{abstract}

CharLotTE SCHWAB

SEPTEMBER 1979

\section{Solar Fnergy Research Institute}

1536 Cole Boulevard

Golden, Colorado 80401

A Division of Midwest Research Institute

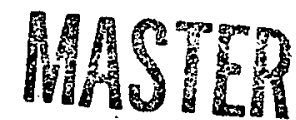

Prepared for the

U.S. Department of Energy

Contract No. EG. $77 \cdot \mathrm{C} \cdot 01 \cdot 4042$ 


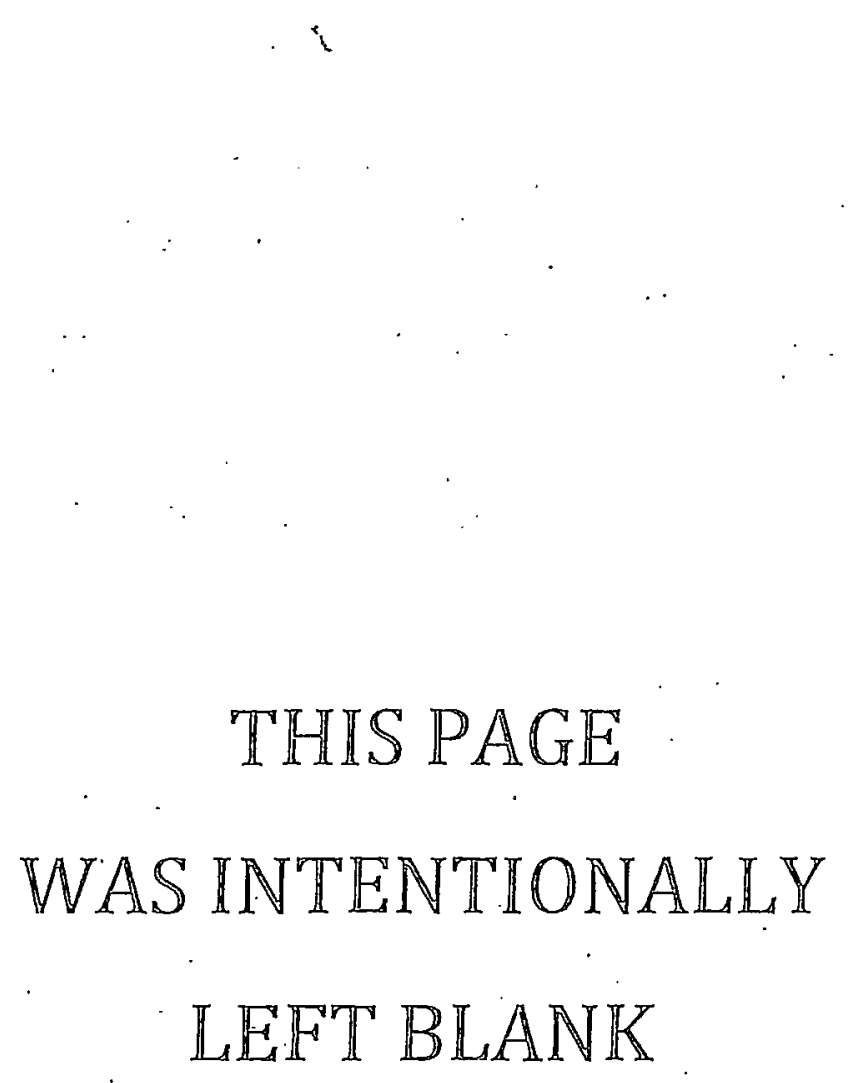




\section{FOREWORD}

This paper on legal considerations in the development and implementation of biomass energy technologies was prepared by the Solar Energy Research Institute (SERI) to fulfill, in part, SERI's solar information dissemination function. The paper is part of the Market Development Branch Law Program, which is in turn part of the overall program of the Technology Commercialization Division.

This is the fifth of eight 1978 Summer Law Intern Papers sponsored by the SERI Law Program. The other seven address (1) the impact of the antitrust laws on the commercialization of solar heating and cooling, (2) licensing arrangements and the development of the solar energy industry, (3) problems in the administration of state solar legislation, (4) legal and institutional implications of providing financial incentives to encourage the development of solar energy technologies, (5) state approaches to solar energy incentives, (6) land-use barriers and incentives to the use of solar energy, and (7) utility rates and service policies as potential barriers to the market penetration of decentralized solar technologies. These eight studies are meant to raise and discuss the primary legal issues that are, or will be, generated by the commercialization of solar technologies.

The author of this paper, Charlotte Schwab, was a student at the University of Colorado Law School while she was participating in the 1978 Summer Law Intern program. She is now a third-year law student at the University of California at Berkeley, where she is a member of the Board of Editors of the Ecology Law Quarterly. The Law Program would like to acknowledge the editorial and substantive assistance provided this paper by Robert Farley of the Market Development Branch, and Seymour Joseph, a law clerk to the Law Program during the Summer of 1979.

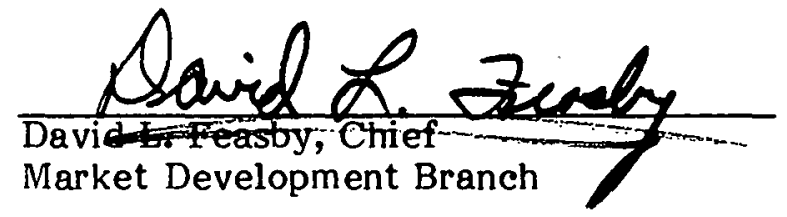

Approved for:

SOLAR ENERGY RESFARCH INSTITUTE

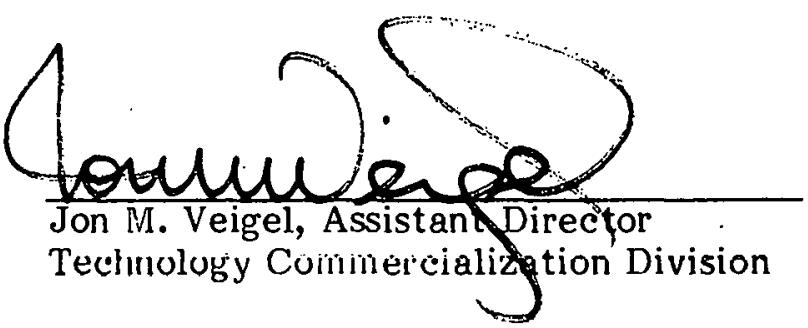




\section{THIS PAGE \\ WAS INTENTIONALLY LEFT BLANK}




\section{SUMMARY}

The photosynthetic energy stored in plant and organic waste materials in the United States amounts to approximately $40 \%$ of the nation's total energy consumption. Conversion of this energy to usable power sources is a complex process, involving many possible materials, conversion technologies, and energy products.

Near-term biomass technologies are predominantly based on traditional fuel use and have the advantage over other solar technologies of fitting into existing tax and business practices. However, no other solar technology has the potential for such large environmental impacts. Unlike the conversion of sun, wind, and ocean thermal energy, the conversion of the biomass energy source, in the form of biomass residues and wastes, can create problems. Environmental impacts may be significant, and legal responses to these impacts are a key determinant to the widespread adoption of biomass technologies.

This paper focuses on the major legal areas which will impact on biomass energy conversion. These include (1) the effect of existing state and federal legislation, (2) the role of regulatory agencies in the development of biomass energy, (3) governmental incentives to biomass development, and (4) legal issues surrounding the functioning of the technologies themselves. Emphasis is placed on the near-term technologies whose environmental impacts and institutional limitations are more readily identified. If biomass energy is to begin to achieve its apparently great potential, these questions must receive immediate attention. 
THIS PAGE

\section{WAS INTENTIONALLY \\ LEFT BLANK}




\section{TABLE OF CONTENTS}

Page

1.0 Introduction $\ldots \ldots \ldots \ldots \ldots \ldots \ldots \ldots \ldots \ldots \ldots \ldots \ldots \ldots \ldots \ldots$

1.1 Biomass Energy Technologies $\ldots \ldots \ldots \ldots \ldots \ldots \ldots \ldots \ldots \ldots \ldots$ 1

1.2 Overview of Legal Framework ................. 3

2.0 Federal and State Research and Development .......... 5

3.0 Development of Near-Term Biomass ............... 7

3.1 Direct Combustion of Wood................. 7

3.1.1 Mill Wastes........................ 7

3.1 .2 Forestry Residues ..................... 8

3.2 Animal Manure $\ldots \ldots \ldots \ldots \ldots \ldots \ldots \ldots \ldots \ldots \ldots \ldots . \ldots \ldots$

3.3 Crop Residues ................................ 10

3.4 Municipal Solid Wastes ..................... 11

3.4.1 Federal Role .......................... 11

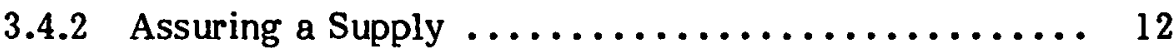

3.4 .3 Conversion $\ldots \ldots \ldots \ldots \ldots \ldots \ldots \ldots \ldots \ldots \ldots \ldots \ldots$

4.0 Use and Distribution of Products $\ldots \ldots \ldots \ldots \ldots \ldots \ldots \ldots \ldots \ldots$

5.0 Mid-term and Long-Range Biomass Programs $\ldots \ldots \ldots \ldots \ldots \ldots$

5.1 Terrestrial Energy Farms.................... 19

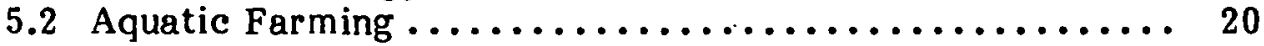

6.0 Conclusions $\ldots \ldots \ldots \ldots \ldots \ldots \ldots \ldots \ldots \ldots \ldots \ldots \ldots \ldots \ldots \ldots$

7.0 References............................. 23 
THIS PAGE

WAS INTENTIONALLY

LEFT BLANK 


\section{LIST OF FIGURES}

Page

1-1 The Biomass Tree $\ldots \ldots \ldots \ldots \ldots \ldots \ldots \ldots \ldots \ldots \ldots, 2$

\section{LIST OF TABLES}

3-1 Sources of Biomass Available for Energy Conversion 


\section{SECTION 1.0}

\section{INTRODUCTION}

\subsection{BIOMASS ENERGY TECHNOLOGIES}

Solar energy, as defined by the Federal Solar Energy Research, Development, and Demonstration Act of 1974 [1], includes photosynthetic energy either stored in plant tissues or already transformed into energy remaining in organic materials or wastes [2]. The term "biomass" refers to materials in which this form of solar energy is stored. Through biological and chemical conversion processes, this stored energy can be transformed into usable energy, such as heat and fuel. Materials readily available for conversion include wood, forestry and agricultural wastes, residues, and municipal solid wastes. There is future potential for recovering energy from harvested natural vegetation, and specially grown land and water energy crops [3].

Although much has been written about biomass as a partial solution to national and world energy problems, estimates of potential biomass energy and land availability for energy crops are highly variable. In the United States, solar energy stored in plant tissues amounts to approximately 30 quads each year [4], or $40 \%$ of the total national energy consumption [5]. The amount of energy in plants has also been estimated at $13.5 \times 10^{15}$ kilocalories (kcal) as compared to $18 \times 10^{15} \mathrm{kcal}$ annual fossil fuel energy consumption [6]. The total solar energy harvested annually in the United States, in the form of agricultural and forestry products, is estimated to be $6.9 \times 10^{15} \mathrm{kcal}$ [7]. This figure represents about half the total fixed solar energy, and may be broken down into food crops$16 \%$, forest products $-18 \%$, and pasture and other forage crops- $-66 \%[8]$.

Paper, pulp, and sugarcane are the major industries in which biomass is a significant source of energy, although food processing, textiles, and chemicals are beginning to utilize the resource. The use of wood wastes supplies nearly $47 \%$ of the total energy consumption of the paper and pulp industry [9]. After juice extraction from sugarcane, a fibrous material (bagasse) remains. The sugar cane industry in Hawaii burns this material to generate steam and electricity for its own use and for sale to utilities [10]. On a national basis, biomass amounted to $2 \%$ of U.S. energy use in 1977 , as compared to $91 \%$ (in the form of wood) in 1850 [11].

Biomass energy use includes production and collection of organic starting materials, conversion of the materials to release a usable energy form, and distribution of that energy or an intermediate product. Biomass energy, even excluding distribution of products, is a very complex field (see Fig. 1-1) and includes many possible materials, conversion processes, and products. Most of these components are still in the research, development, and demonstration phases, with only a small number commercialized [12].

The most familiar biomass energy form is generation of heat through direct combustion of wood in fireplaces and wood-burning stoves. Large-scale energy technology includes taking forest residues or standing (and future) forest biomass, and burning these products to produce process steam, which in turn generates electricity [13]. A number of woodfired steam/electric facilities are operational or in the planning stages [14]. Bulky, highmoisture content, and variably sized wood pieces may present major transportation and processing problems if the conversion facility is not on-site. Dried, densified, uniformsized pellets (Densified Biomass Fuel-DBF) made from cut trees or forest residues may increase the potential for biomass use in such steam/electric facilities [15]. Direct com- 


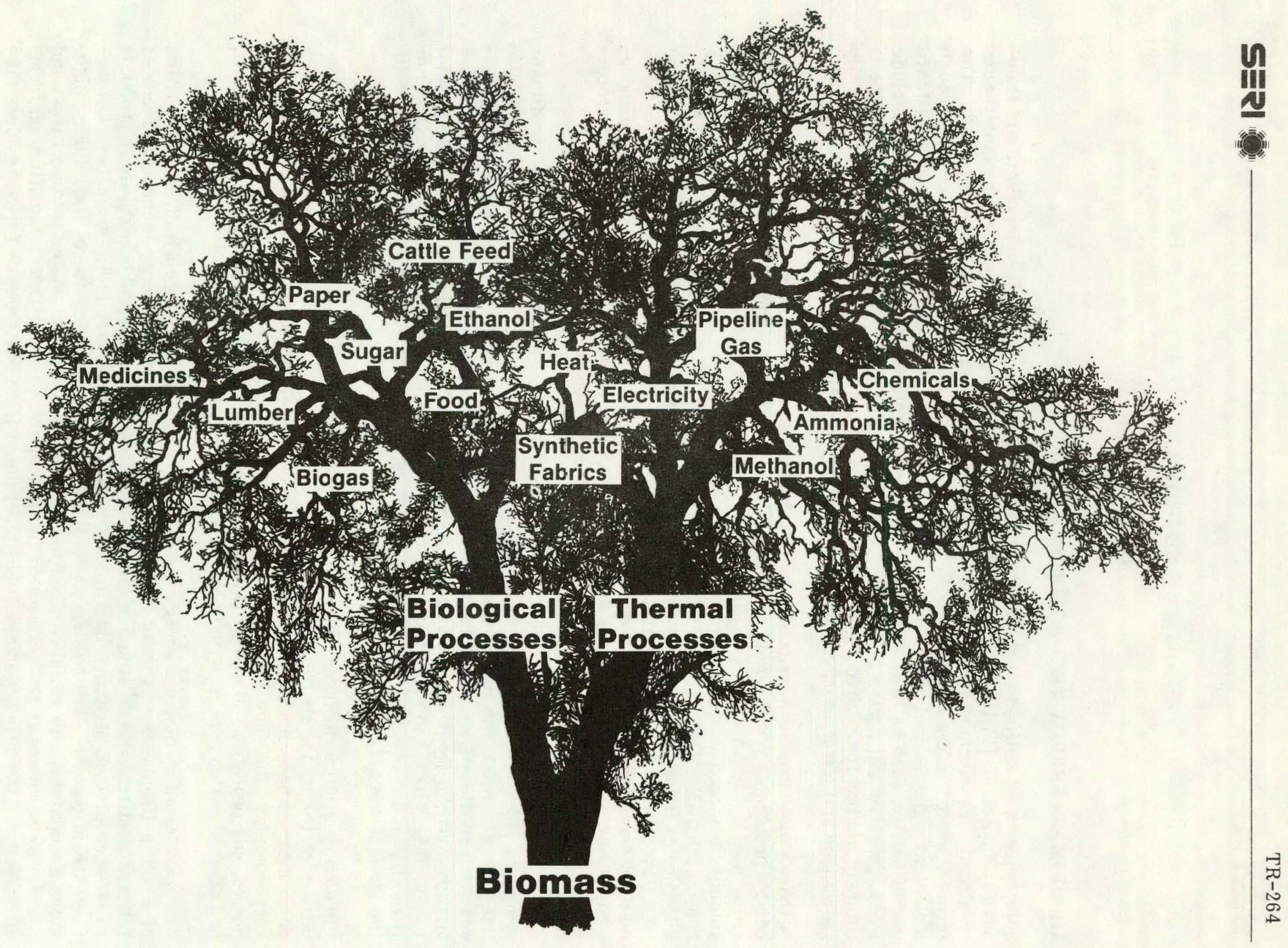

Figure 1-1. The Biomass Tree

Photosynthesis-Mother of Life 
bustion of biomass is simpler than the other conversion systems and may have a high future use potential, particularly where it can be utilized near the resource [16].

Thermochemical conversion utilizes heat to bring about chemical reaction in the biomass. There are several such processes under investigation in commercial operation. Theoretically, all forms of biomass can be processed thermochemically, with the goal of producing gaseous and liquid fuels which have higher heating values than the original material. Such processes could fulfill the fuel needs of conventional heating systems. Several investigations and operations are also underway to produce a powdered fuel thermochemically, of ten referred to as refuse-derived fuel (RDF) [17].

Examples of such ther mochemical conversion processes are pyrolysis, a chemical decomposition with heat in the absence of oxygen at atmospheric pressure, and hydrogenation, the addition of hydrogen to organic compounds to obtain an oil with a high hydrogen to carbon ratio [18]. Gasification of biomass can also be accomplished through thermochemical conversion, and is seen as a means of converting solid biomass materials into gases which could be used directly in conventional gas-fired industrial boilers [19]. Gasifiers using wood and municipal solid wastes as starting materials are presently in operation.

Bioconversion processes use microorganisms to produce various materials, including methane and alcohols, as promising energy sources. Digestion of organic matter proceeds in the absence of oxygen (anaerobic) and generates a mixture of $60 \%$ methane [20] and $40 \%$ carbon dioxide, plus very small amounts of sulfur and nitrogen compounds. The digestion process can take place with most cellulosic materials [21], but is presently primarily applicable to animal manures and municipal sewage. The process takes place at atmospheric pressure and slightly elevated temperatures, and therefore may require some energy input to maintain the temperature. Several anaerobic digesters are either operational or in the planning stages, particularly those utilizing cattle manure from feedlots or dairy farms [22]. Anaerobic digèstion takes place naturally in organic materials deposited in sanitary landfills. Normally, the methane escapes, but in some cases is being recovered and put to use [23].

Alcoholic fermentation is a long-established bioconversion process in which yeast cell enzymes act upon carbohydrates to yield ethyl alcohol. Although the technology has long been in use in the distillery industry, it is in the laboratory investigation stage as a largescale energy source [24]. The primary goal is to produce ethyl alcohol on a scale large enough to allow its extensive use as a gasoline additive [25].

Other possibilities exist for chemical and biological conversions to generate fuels, such as biological hydrogen generation [26]. However, they are of such long-term, lowemphasis research status that they are only of theoretical value.

\subsection{OVERVIEW OP LEGAL FRAMEWORK}

The current availability of resources, the potential of conversion technologies, and the current markets in which commercial competition is already feasible indicate the great promise of biomass as a significant source of U.S. energy needs [27]. In addition, biomass can provide a unique contribution among solar technologies. It can address the nation's most critical energy problem of displacing and substituting for imported liquid fuels. Biomass is a stored solar chemical energy, not requiring additional storage technologies, and is a traditional fuel-based technology which fits into existing tax and business practices [28]. 
Legal overviews of other solar technologies have recently been published [29]. However, biomass energy comes from not one, but several sources and conversion processes. Moreover, biomass may be converted into many forms. Also, one major difference between biomass and wind energy conversion systems, ocean thermal energy conversion, and direct solar conversion (such as photovoltaics and solar heating and cooling) is that the latter three raise no problems concerning the production of the energy source itself. Rather, considerations concerning the energy source center around rights to wind, sun, or use of the ocean gradients.

This paper will discuss the major legal areas which will impact on the development and implementation of biomass energy conversion technologies. First, the major applicable federal legislation, state legislation, and regulatory agencies will be examined. Given the present state of the technology, federal funding and regulation are the primary incentives to development. Second, legal considerations concerning the functioning of the technologies themselves will be discussed. 


\section{SECTION 2.0}

\section{FEDERAL AND STATE RESEARCH AND DEVELOPMENT}

The impetus for federal research and development efforts lies in the federal Nonnuclear Energy Research and Development Act of 1974 [30] and the Solar Energy Research, Development, and Demonstration Act of 1974 [31]. Specifically included in these statistics under solar technologies to be addressed is "the conversion of cellulose and other organic materials (including wastes) to useful energy or fuels" [32]. The present research, development, and demonstration programs are primarily in the U.S. Department of Energy (DOE). Three biomass technologies have been identified by DOE as being of near-term applicability: (1) the direct combustion of wood residues to provide industrial process heat, electricity, and residential heating; (2) the anaerobic digestion and direct combustion of agricultural residues to provide on-farm agricultural fuel; and (3) the fermentation of excess agricultural crops to provide ethanol as a liquid transportation fuel [33]. These programs are being handled by DOE Resource Managers within the Office of Commercialization and Solar Applications and the Office of Resource Applications [34].

The U.S. Department of Agriculture (USDA) has recently received a statutory mandate to enter research and development in biomass [35]. The Fuels from Biomass Systems Branch of DOE intends to transfer its activities concerned with the commercialization of animal manure conversion technologies to the USDA by 1980 [36]. Representatives of both DOE and USDA are currently involved in a joint steering committee effort designed to identify areas of cooperation and expertise for future placement of energy programs [37].

Although DOE's Urban Waste Technology Branch handles some research and development aimed at utilization of municipal solid wastes, the U.S. Environmental Protection Agency (EPA) has primary responsibility in this area. Under the Resource Conservation and Recovery Act of 1976 (RCRA) [38], EPA is authorized to conduct research, development, and demonstration activities, including grants to states, municipalities, and regional authorities for resource recovery systems. Although RCRA is primarily aimed at promoting solid waste disposal plans and systems for municipalities, it mentions energy recovery several times and is, in the broad sense, also applicable to agricultural solid wastes, such as manure. [39]. The RCRA will be discusssed in greater detail in connection with municipail solid wastes.

Several new federal initiatives affecting biomass have recently been proposed by President Carter [40]. A residential tax credit for wood stoves would utilize the $15 \%$ conservation credit of the 1978 National Energy Act to promote increased use of our nation's wood resources. A pilot program for timber-stand improvement and firewood marketing is intended to meet the increased fuel demand for wood stoves. Making the current gasohol exemption from gasoline tax permanent is sought to increase the availability and use of gasohol. Projects are being developed to provide industrial process heat for industries having a high potential for biomass utilization, such as paper and pulp and food processing. Programs for on-farm and large-scale methane generation from animal wastes are planned for implementation by the Farmers Home Administration.

State biomass developments have not been nearly as comprehensive as federal efforts. California has instituted a Biomass Fuels Program, and a proposed residue utilization bill that would encourage the conversion of forestry and agricultural residues into useful energy [41]. The high cost of fuel oil in the Northeast and the presence of abundant timber 
reserves has been a power incentive for conversion to woodburning in Maine. One study has indicated that $50 \%$ of Maine's energy needs could be met by wood in the mid1980s [42]. 


\section{SECTION 3.0}

\section{DEVELOPMENT OF NEAR-TERM BIOMASS}

The major categories of residues available for ready biomass utilization are lumber-pulp mill wastes, forestry residues, animal manures, and crop surplus. The lumber-pulp mill wastes presently supply energy needs to the pulp-paper industry, usually through combustion. These materials are on-site, and the industries have adapted their operations to utilize them. Forestry and crop residues and animal wastes, however, are usually not near a conversion facility; their removal and transportation could present substantial economic and ecological problems. Because the materials are so widespread, their volume is difficult to estimate; when estimates are made, economic and ecological constraints may greatly reduce the amount perceived as readily available. Table $3-1$, for example, illustrates volume estimates from two recent sources.

Table 3-1. SOURCES OF BIOMASS AVAILABLE FOR ENERGY CONVERSION

\begin{tabular}{lccc}
\hline & \multicolumn{2}{c}{ Million $^{\mathrm{a}}$ tons dry weight per year } \\
\hline Source of Biomass & $\begin{array}{c}\text { Hypothetically } \\
\text { Available }\end{array}$ & $\begin{array}{c}\text { Readily } \\
\text { Available }\end{array}$ & $\begin{array}{c}\text { Residues/ } \\
\text { Wastes }^{b} \\
\text { Available }^{\mathrm{b}}\end{array}$ \\
\hline Livestock Manure & 255 & 128 & 26 \\
Field Crop Residues & 430 & 0 & 100 \\
Forestry Residues & 340 & 44 & 80 \\
\hline
\end{tabular}

apimentel figures are million metric tons.

b Schooley, F. A.; Alich, J.; et al. An Evaluation of the Use of Agricultural Residues as an Energy Feedstock-A Ten Site Analysis. Vol. 1 and 2. Menlo Park, CA: Stanford Research Institute; 1977.

\subsection{DIRECT COMBUSTION OF WOOD}

\subsubsection{Mill Wastes}

Mill wastes are currently the most widely utilized biomass fuel. The pulp and paper and wood products industries have burned surplus mill residues to replace natural gas, oil, coal, and propane as fuel sources for their manufacturing processes [43]. Recycling mill wastes as fuel is an advantageous use of biomass because it eliminates disposal problems, reduces air pollution from dust accumulation, and utilizes available on-site resources.

Because mill residues are costly to collect and transport, the source of the fuel needs to be close to the conversion facility. For example, a textile plant in Alabama is able to use a wood-fired boiler to generate steam for its bleaching and dyeing needs due to the proximity of a local timber management firm [44]. 
The technology for efficiently burning mill wastes is presently commercially available. Cyclones for particulate reduction seems to be the only control needed to maintain environmental quality [45].

\subsubsection{Forestry Residues}

\subsubsection{Production and Collection}

Forestry residues (other than mill wastes), considered to be sources of biomass, are field logging residues and standing trees with no commercial timber value [46]. Much of the field residue is commonly known as "slash" and is comprised of treetops and limbs that are removed and left on site. Slash averages about one-third of total wood removed, and the stumps and roots average about another one-third [47]. Estimates of future total residue availability include projections on more efficient harvesting and removal of slash and increased forest productivity. While there is little question that the residues represent a large energy source, economic, environmental, and land management problems must be resolved before the energy potential can be realized.

While forestry residues are a potentially much larger biomass resource than mill wastes, the environmental impacts that need to be addressed are considerably greater. Increased erosion and nutrient depletion of forest land can result from slash removal and log harvesting. The severity of these problems will depend on the harvesting method and site chosen [48]. A Vermont study indicated that whole tree harvesting resulted in considerable soil depletion and water sedimentation [49]. The steeper the site terrain, the greater will be the soil damage caused by skidding logs [50]. The more inaccessible the area, the more the building of roads and increased truck traffic will affect the surrounding environment [51].

On the positive side, removal of residues could decrease the frequency and severity of forest fires, a significant source of air pollution in some areas [52]. Slash is also unsightly [53]. The DOE Fuels from Biomass program plans to support research on the effects of forestry residue removal on soil fertility and air and water quality [54].

\subsubsection{Ihe Pederal Kole}

The Federal Government owns approximately $20 \%$ of the nation's commercial forest land, almost $40 \%$ of its supply of merchantable timber, and over $60 \%$ of its sof twood sawtimber. Most of these lands are managed by the U.S. Forest Service with smaller amounts managed by the Bureau of Land Management (BLM). Federal government BLM and Forest Service policies on land availability and use will greatly affect the total amount of available forest residues [55].

Any increased water quality degradation through runoff caused by removal of slash would probably be considered outside the coverage of the Federal Water Pollution Control Act Amendments of 1972 [56]. In formulating land management policies, however, the Forest Service would consider such environmental factors. Control over timber harvesting on Forest Service lands relies primarily on timber sales contracts stipulations concerning methods of operation and safeguards which must be taken to prevent or minimize adverse effects on lands and waters [57]. 
The practice of clear-cutting, as allowed by the Forest Service, was found to be in violation of the Forest Service Organic Act of 1897 [58], in West Virginia Division of the Izaak Walton v. Butz [59]. The present controlling statute is the Forest and Rangeland Renewable Resources Planning Act of 1974 as amended by the National Forest Management Act of 1976 (RPA/NFMA) [60]. Any move to require slash removal by all contractors could be tested under RPA/NFMA, and would probably require an environmental impact statement under the National Environmental Policy Act (NEPA) [61]. While the Forest Service presently requires slash removal in some areas, the advisability of such a practice would have to be carefully examined in light of factors such as topography, stream bed proximity, necessity for further road construction, and previous clear-cutting. Assessment may have to be done on a forest-to-forest or smaller scale basis with decisions made for harvesting in specific areas. Public lands could become a further source of forest residues if slash removal can be shown to be a silviculturally and environmentally sound practice [62].

\subsubsection{Conversion}

The conversion of forestry residues into useful energy can also pose environmental problems. Wood stored without protection from rainfall may cause pollution by the leaching of bark decomposition and tannic acid into run-off waters [63]. Studies of industrial wood boiler applications indicate that wood-oil fuel combinations produce three times the particulate emissions of oil-coal mixtures [64]. Large wood-fired boilers also frequently require a secondary combustion process because of the variable size and moisture content of the wood chips used. Secondary conversion processes are generally absent in residential space heating stoves. Widespread use of residential wood heating is a distinct possiblity in northeast urban areas [65]. If significant concentrations of partially combusted materials are released in the air, substantial health problems would be posed [66].

\subsection{ANIMAL MANURE}

While estimated production of animal manures is in the range of 250 to 255 million tons/year (see Table 3-1), most of that manure is on open range, and therefore, impractical and uneconomical to collect. Manures available for energy conversion are those which are concentrated in dairies, feedlots, and other confined animal raising operations. Most research and development has been concentrated on dairies and cattle feedlots, but energy recovery through anaerobic digestion is also applicable to swine and poultry wastes [67]. All four types of operations (dairies, beef cattle in feedlots, swine, and poultry) would supply enough manure to make methane production feasible [68]. Conventional cattle feedlots could supply the greatest quantities of manure. Because manure is usually collected on a periodic basis after it has dried and become mixed with foreign matter, it requires addition of large quantities of water and the use of a degritting phase. Anaerobic digestion systems are in operation at large cattle feedlots [69]. The FFBP considers anaerobic digestion of manure to be a near-term system (ready by or before 1980) and is funding a demonstration facility in a feedlot at Bartow, Florida [70]. In 1978/79, the Calif ornia Energy Commission plans to choose a Southern California highintensity dairy farm area suitable for methane production, and to do site-specific analyses of the first installation [71].

The major legal considerations in animal feeding operations are land-use controls, water quality regulation, and nuisance actions. Animal wastes are a major source of agricul- 
$=-\dot{x}$

tural water pollution [72], and attempts at control of the pollution are aimed at controlling drainage and disposing of accumulated manures [73]. Concentrated animal feeding operations are covered by the Federal Water Pollution Control Act Amendment of 1972 (FWPCAA) and various state regulations [74]. Because only large operations are included within the regulations, water pollution from animal wastes continues to be an environmental problem [75].

While accumulations of manure are of ten viewed as a waste handling problem by feedlot operators and farmers [76], anaerobic digestion systems could produce energy and have a significant positive impact on water quality. Such incentives could lead to greater numbers of feedlots and enclosed building swine-raising operations [77]. For swine operations, estimated costs for preventing water discharge runs from $\$ 9 /$ head for 100 -head or fewer operations to $\$ 1 /$ head for 1,000 -head operations [78]. Installation of an anaerobic digestion system requires a sizeable capital investment. A waste handling system could be designed to feed into the digester, and the operator could get a return in the form of methane to supply internal energy needs and to be sold if the gas exceeds on-site needs. The effect of pollution control regulations and other waste handling problems on the economics of operation were found to be the major factors that could convince dairy farmers to put their manure to work as an energy resource [79].

The conversion of animal wastes into medium Btu gas by anaerobic digestion, however, creates additional environmental concerns. The dewatering effluent will contain sludge and wastewater that needs to be treated before disposal [80]. After mechanical dewatering or heat drying, sludge could be applied as a fertilizer, but could be a source of water pollution if runoff and/or percolation are not controlled. Although most water-based treatments of the sludge are considered to be odorless and sanitary because of the nature of the digester sludge, there is potential for offensive odors and subsequent private nuisance actions.

An attractive aspect of anaerobic digestion systems is the potential for recycling of sludge as animal feed or feed additives [81]. At this point, there is little information on the residual effects of antibiotics and growth hormones regularly fed to animals [82] or pesticides or herbicides that may be on or in plant biomass used as a feedstock. Such materials may render the sludge undesirable as a feed, particularly af ter several cycles of refeed. Direct feeding of animal wastes is prohibited by the Food and Drug Administration (FDA) [83], but the FDA has not proposed standards on waste recycling [84]. Some states (e.g., California and Mississippi) have established feed and waste recycling standards [85].

\subsection{CROP RFSIDUES}

'The total amount of residues and the amount available for collection has been invariably estimated (see Table 3-1). A detailed analysis of production of crop, forestry, and animal residues has been conducted, including a county-by-county computerized national inventory [86] which serves as a data base for an evaluation of the technical and economic feasibility of utilizing crop residues as an energy source.

The Stanford Research Institute (SRI) study established the total amounts of residues as sufficient to serve as an energy feedstock. Variations in amount available are based on varying viewpoints on the advisability of removing the residues. Removal of crop residues is a very complex problem. For example, rice and straw residues are normally re- 
moved to allow planting of another crop. Where this is not normal practice, many other considerations, such as farmer attitudes and the guidelines of the USDA-Soil Conservation Service, come to bear [87]. Research is underway, funded by USDA and DOE [88], to determine whether residues should be removed and, if so, how much, on a crop- and sitespecific basis.

It has been estimated [89] that allowing biomass residues to remain returns approximately $25 \%$ of the nitrogen, $40 \%$ of the phosphorous, and $75 \%$ of the potassium back to the soils. By preventing wind and water erosion, residues also help retain organic matter. Residues also contribute to soil structure, reduce direct sunlight on the soil surface, and serve as food material for soil organisms that are critical to crop production [90]. Residue removal could also contribute greatly to fugitive dust emissions and to sediment in waterways, by allowing greater runoff.

In addition to utilization of crop residues, research has focused on the fermentation of sugar cane and sweet sorghum to produce ethanol [91]. A Brazilian study has identified stillage disposal as the major environmental problem likely to be encountered in fermentation treatment [92]. Fertilizer or animal feed additives, from the fermentation of corn and wheat, can be derived from stillage; but treatment by conventional biological pollution control processes is very energy intensive [93].

\subsection{MUNICIPAL SOLID WASTES}

Municipal solid wastes (MSW) are an attractive biomass resource because conversion to energy will also lessen the environmental problem of waste disposal. There are at least 16 plants presently in operation that are burning urban garbage as fuel [94]. Two systems are presently being used commercially: mass burning incinerators and combined systems [95]. The former burns waste in a processed or unprocessed form in a boiler lined with water-filled tubes that transform the released heat into steam. The latter uses process waste, known as refuse driven fuel (RDF), as a supplement to coal, oil, or natural gas in a modified industrial or utility boiler.

\subsubsection{The Federal Role}

The trend in federal legislation in solid waste disposal should have a significant impact on access to MSW for resource recovery operations.

The first federal solid waste disposal legislation was the Solid Waste Disposal Act of 1965 [96] (SWDA), which expanded the federal role to include technical and financial assistance to state and local governments, as well as grants to those states which (1) developed statewide solid waste management plans, and (2) designated a single state agency to implement such plans [97]. The Resource Recovery Act of 1970 [98] (RRA) amended the SWDA to include promotion of demonstration, construction, and application of solid waste management and to provide for promulgation of guidelines for solid waste collection, transport, separation, recovery, and disposal systems [99]. The RRA recognized energy and materials recovery from waste as a means of reducing the volume of waste for disposal [100]. It addresses four major areas: (1) state/local solid waste management plans, (2) government procurement of recovered materials, (3) federal facilities, and (4) hazardous wastes. 
The impact of the Resource Conservation and Recovery Act on biomass technologies comes from its emphasis on energy recovery systems that may be part of solid waste management plans [101], and its inclusion of the recovery of energy in the definition of "resource recovery" [102]. This encouragement serves as an impetus to state/local governments to include energy recovery facilities in their solid waste management plans [103]. Federal facilities will be required to comply with state and local standards, including payment of any charges set for depositing refuse at a facility [104]. A major factor in the formulation of RCRA was concern over environmentally degrading dumps and landfills, and the rapidly dwindling land available for such sanitary landfills. Because of the capital-intensive nature of recovery plants, however, it is of ten less expensive to deposit MSW at landfills and dumps.

Unless state and local governments can deliver MSW to a recovery facility on an economically competitive basis, there may be a failure of supply, particularly if a facility serves a large geographical area [105]. Implementation of solid waste management plans could gradually phase out opening of new landfills and dumps, making resource recovery facilities the primary deposit points.

\subsubsection{Assuring a Supply}

To gain financing and assure economical operation of a recovery program, there must be a certain guaranteed supply of MSW. A facility that contracts to supply a minimum of steam, electricity, or liquid/solid fuels would require a certain volume of material. Solid waste management plans should include this consideration in their structure.

At present, there are two methods that are commonly used to assure the delivery of MSW to resource recovery plants on a regular basis. One is to require the delivery of MSW to a regional facility. Municipalities may not wish to cooperate, however, and the power of the local governmental agency may be questioned [106]. The second approach is to negotiate long-term contracts with municipalities [107], commltting them to delivery of unirimum amounts [108].

While the RCRA expresses the federal interest in energy recovery from solid waste, it leaves the control of collection and disposal of refuse to state and local authorities. In order to qualify for technical and financial assistance, a state or region must develop a solid waste management plan, subject to EPA approval [109]. In general, the region must be large enough to incorporate advanced technology and high-cost disposal equipment, yet limited in size by transportation costs and geographic, geologic, climatic, and hydrologic characteristics [110]. Particularly in the East, where large cities are geographically close, an interstate region may be more cost-effective and involve shorter distances for transportation of MSW.

Some states have laws prohibiting the importation of solid waste [111]. These statutes are intended to prevent the dumping in one state of refuse originating in another state, but could have the unforeseen effect of hampering recycling efforts. Fortunately, the United States Supreme Court has recently held a New Jersey statute of this type impermissible under the Commerce Clause [112]. As energy products increase in value, landfill space decreases, and resource recovery facilities increase in number. These statutes should be repealed or amended to accomodate regional transportation of MSW [113].

Existing sanitary landfills have been viewed as "biomass mines" because of the potential for recovery of a resource from an intact biomass source. As such, the mines do not pre- 
sent the same considerations as do collectible, transportable MSW. In view of RCRA's energy recovery element, the EPA could consider methane recovery from existing landfills as a positive feature in considering state plans.

\subsubsection{Conversion}

Because conversion of MSW involves direct combustion, it can be a source of air pollution as well as energy. Gaseous emissions are not a significant problem because of the low sulfur content and combustion temperatures of refuse, but particulate controls are necessary [114]. There are also indications that higher concentrations of such toxic substances as cadmium and mercury are in the emissions of combined RDF and coal combustion than in plants using only coal [115].

In processing wastes to obtain RDF, substantial quantities of water are needed to remove noncombustibles and to reduce the particulates to common sizes. Without proper treatment of the waste water, the effluent will be corrosive and can pose very dangerous impacts on water [116]. Awareness of these environmental problems should lead to meeting EPA standards by applications of conventional technologies. Mixed waste processing would then be in a position to reach its potential of supplying energy while reducing landfill requirements by up to $95 \%$ [117]. 


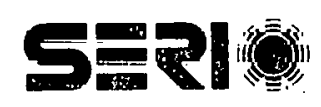




\section{SECTION 4.0}

\section{USE AND DISTRIBUTION OF PRODUCTS}

The major types of products generated are: (1) solid fuels-e.g., wood, densified biomass fuel (DBF), and refuse-derived fuel (RDF); (2) gaseous fuels, such as methane and synthetic natural gas (SNG); and (3) liquid fuels, such as ethanol, methanol, and fuel oils. A conversion facility could treat direct sources (such as wood or municipal solid waste) to generate heat, steam, or electricity, or to make gaseous or liquid fuels. Also, methane from a digester or a sanitary landfill could be burned for direct heat use or to generate electricity, be sold into a natural gas pipeline, or possibly be compressed and cooled for movement in tanks. Solids, such as DBF and RDF, could be used alone in modified existing combustion facilities or in co-fired operations in conjunction with coal. Fuel oils will probably be transported and used in the same way as petroleum-based oils. Methanol and ethanol have the greatest potential as fuel additives, and could be transported as are chemicals and gasoline.

The starting biomass material may be transported and used in its original form, as wood or MSW, or, particularly in the case of wood, converted with mobile equipment on-site into DBF. Municipal solid waste, because of its dispersed nature, would have to be transported through existing systems to a conversion facility, to be converted into RDF. This densified fuel could then be converted into a direct energy form on-site or transported elsewhere for use. There is potential for biomass, in the form of DBF, to become a standard commodity fuel which is easily shipped, stored, and converted. Transportation of DBF would be subject to regulation by the Interstate Commerce Commission (ICC). Carriers would have to be issued certificates of "public convenience and necessity" [118] to serve the routes between production, conversion, and use sites. Under the Interstate Commerce Act [119], DBF would be subjected to the classification of property system used by the ICC [120]. Several characteristics of the product itself [121] are considered along with the transportation territory in the classification scheme. In general, a "just and reasonable" classification is required [1.22].

Densified biomass fuel made from municipal solid waste or forestry residues are secondary or recycled materials, but DBF from harvested trees would be derived from raw materials. The difference in freight rates between raw and recycled materials of the same type was the subject of the well-known Students Challenging Regulatory Agency Procedures (SCRAP) litigation [123]. Although the rate discrimination and recycling issues have not been resolved by SCRAP, its establishment of the importance of environmental values in the rate-making process could be important for biomass materials. The energy recovery factor should also be considered. The ICC has made some attempts to correct inequities by establishing unrestricted licensing privileges for motor carriers transporting waste products for reuse [124]. Under most circumstances, energy products transported by agricultural cooperatives for the use of members and most purposes of the co-op would be exempt from regulation by the ICC [125].

The provisions in RCRA relating to commercialization [126] and federal procurement [127] of recovered materials should facilitate development of appropriate and economical transportation of secondary source DBF. This should apply also to raw material DBF since the products would be very similar. A strong federal procurement policy could stimulate effective use and distribution of $\mathrm{DBF}$, but the effectiveness of the policies set under RCRA have been questioned [128]. This is an important area for further investigation and economic stimulation. 
Liquid and gaseous fuels, though of different origin, should be channeled into existing transportation modes. The greatest impact of the liquid fuels is expected to be in the transportation sector itself [129]. A model for the use of a possible regulatory scheme is the "gasohol" program [130]. The mixture of $10 \%$ to $25 \%$ alcohol with gasoline shows potential of improved mileage, higher octane, and lower emissions. A major goal is decreased gasoline use. Gasohol is being sold in Illinois [131] and Iowa [132], and plans for its sale are underway in at least 20 more states [133]. Several bills concerning gasohol are pending before Congress, including one calling for a federal mandate for a 1:9 blend for all automobile fuels. Two recent regulatory decisions render gasohol more attractive to commercial producers and suppliers. One makes biomass fuel producers eligible for a $\$ 2 /$ barrel subsidy from refiners using domestic crude oil [134]. This also applies to fuel from shale and solid wastes and, therefore, has application to fuels other than alcohol. The second allows marketers of gasohol to pass on to consumers the added cost of the alcohol fraction [135]. Previously, the alcohol has been classed as a nonproduct additive, the cost of which could not be passed on. The DOE's Economic Regulatory Adminstration (ERA) indicated that the new rule would remove an unintended regulatory impediment to the selling of gasohol [136]. Still pending is an EPA decision on whether to classify alcohol as a fuel additive, a decision which would require additive testing prior to further marketing [137]. This could slow the marketing and distribution of gasohol. Regulatory policies and research priorities of the EPA and DOE have been cited as impediments to implementation of gasohol and other biomass programs [138]. All biomass-produced liquid fuels with potential for use in motorized vehicles will probably be subject to longterm studies and extensive regulation from government agencies.

Biomass-derived gaseous fuels may be distributed in existing natural gas pipeline systems if the gas is produced at pipeline quality or upgraded to that level [139]. A large feedlot in Oklahoma [140] is currently selling upgraded SNG to the pipeline system of the Natural Gas Pipeline Company of America. Following a petition by the Natural Gas Pipeline Company, the Federal Power Commission (FPC) ruled that gas produced through anaerobic digestion was not "natural" gas; therefore, the producer was not subject to the jurisdiction of the FPC [141]. The pipeline system and the Natural Gas Pipeline Co. (NGPC), however, are an interstate operation; once the $S \mathrm{SG}$ is introduced into the pipeline and commingled with natural gas, rate setting by the interstate company is subject to FPC regulation. In the same proceeding, the NGPC requested specific authority to pass through increases in the contract price for the gas, either through the tariff purchase gas adjustment provision in the original contract, or research and development cost tracking provisions. NGPC and the gas producer tried to tie the requested annual adjustments to the consumer price index, but the FPC said it could not substitute such a measure for its regulatory function [142].

Because natural gas is held at an artificially low price, SNG is not economically competitive. Since the producer is not subject to FPC (now Federal Energy Regulatory Commission) jurisdiction, the actual costs to the producer would not necessarily have to be documented. A company such as NGPC, moving into a new and promising field, is trying to recover the higher cost of the product. At the same time, the regulatory commission will not grant automatic consumer price index increases, but neither the pipeline company nor the FPC has access to actual costs to the producer. The NGPC is committed to this field, but sees this situation as a regulatory hiatus with significant negative potential to commercialization of SNG [143]. Because of this type of problem, regulatory limits on the use of natural gas, or regulations to require pricing of SNG on an incremental cost basis, are required to mitigate the competition between biomass products and natural gas for industrial uses [144]. 
Feedlots and paper mills could operate as integrated systems supplying their own power needs and not producing energy products for outside use. A feedlot could diversify operations, including a slaughter and packing house on one site in order to use all the gas produced without having to sell externally or burn off excess gas. Existing regulatory constraints can be incentives to operate in this manner [145].

An internal use system would usually be self-sufficient, but, particularly with a plant material source, could be subject to shortages of biomass materials. Such an operation could require a conventional backup power supply and, therefore, the services of a public utility. A new facility could desire to have or be required to install a backup system. The same issues would arise as affect the use of solar collectors or wind energy conversion systems (WECS) [146]. Although the same problems in rate setting and requirements for financing of backups would arise, the shortage of supply would be very rare. On the other hand, a self-contained system could also connect with a power grid to sell small amounts of excess power, particularly if the facility is generating electricity. A recent decision by the New York Public Service Commission resolved some of the questions concerning the interaction of a usually self-contained system with a public utility in New York [147]. Concerning a WECS operation, the Commission ruled that Consolidated Edison has to supply the operation, accept its excess electricity, and set rates for movement of power in both directions. This type of approach should be applicable to biomass systems.

The diversity of possible biomass systems presents a variety of possible interactions with the ultimate user. An intrastate operation may be subject to regulation by a state public utilities commission (PUC), depending upon the type of power produced and the state definition of a public utility. Two types already in operation and not subject to such regulation are: (1) generating facilities that sell power through contract agreements to a single industrial user [148], and (2) those that sell to a single municipal utility [149], which is exempt from regulation itself by virtue of being publicly owned. The Mt. View, California, sanitary landfill operation [150] is in start-up and will supply gas to Pacific Gas and Electric (PG\&E). As a demonstration project, PG\&E will initially receive the gas free of charge, with plans to pay $\$ 0.17 / \mathrm{million} \mathrm{ft}^{3}$ in the next phase. Presumably, PG\&E would have to petition for PUC approval to include a full charge for the gas in their rates if the project reaches that point. An existing public utility would remain under PUC jurisdiction even if it converted to a biomass fuel supply. Because of the cost of biomass sources, extensive rate-setting hearings would be necessary to establish rates, including operating costs of demonstration facilities. Permission for the construction and operation of a new plant would be subject to PUC issuance of a certification of public good or convenience and necessity.

A biomass conversion facility that sells gas to an interstate pipeline system or supplies power to an electric power grid could be subject to regulation by the Federal Energy Regulatory Commission: If the sale of electricity results in interstate distribution through a power grid, the facility would be subject to FERC jurisdiction. If the facility is deemed a "public utility" [151], it could be directed by the FERC to establish connections with other facilities [152] and would be subject to regulation of its rate [153]. Under the Public Utility Regulatory Policies Act of 1978 (PURPA), a biomass conversion facility may be exempted from state and federal regulation if it qualifies as a cogeneration facility [154]. 


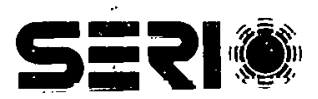




\section{SECTION 5.0}

\section{MID-TERM AND LONG-RANGE BIOMASS PROGRAMS}

\subsection{TERRESTRIAL ENERGY FARMS}

Silvicultural energy farming and high-yield herbaceous crop development are viewed by DOE as mid-term biomass potentials, capable of significant energy contributions by the year 2000 [155]. Depending on the forestry and crop residues that become available, thermochemical conversion possibilities include gasification of cellulose feedstocks to medium and high Btu gas, methanol, and ammonia, and the liquification of wood to fuel oil. Biochemical possibilities include fermentation of cellulose feedstocks to ethyl alcohol and the anaerobic digestion of agricultural residues to medium Btu gas. Although the technologies are not commercially feasible as yet, identifying the environmental and institutional limitations of the biomass as resources is part of DOE's mid-term strategy [156].

The problems likely to be encountered by silvicultural energy farming [157] and herbaceous crop development [158] are much the same as for near-term utilization of forestry and crop residues, only on a larger scale. Major impacts on erosion control, water pollutant removal, wildlife habitat, and outdoor recreation need to be considered, even when marginally productive land is used [159].

Under NEPA, the Federal Government is required to prepare an environmental impact assessment (EIA) on major actions significantly affecting the quality of the human environment. An environmental impact statement (EIS) may be required upon review of the EIA. The EIA is in preparation for the pilot biomass plantation [160] funded by the Fuels from Biomass Program [161]. This pilot project is on public land, but there is potential for governmental (federal or state [162]) eminent domain actions to establish such research, development, and demonstration projects on private lands. Any such actions would also be subject to the federal NEPA requirements and state environmental statutory requirements.

National forest land is planned for use for a pilot energy farm. A MITRE study suggests that public lands be used in at least the research and development (R\&D) stages to avoid the problems acquiring large areas of private land [163]. MITRE also includes 42 million acres of U.S. Forest Service (USFS) land in its estimates of land availability and projects production of biomass on $10 \%$ of USFS available land actually being put to use [164]. Two suggestions are made by MITRE: (1) interplanting biomass candidates with conventional forest crops and (2) using portions of timber company holdings (leases?) for biomass monoculture [165]. It has also been suggested that USFS legislation must be amended by Congress to make national forest land available for energy production [166].

Water availability is another important consideration in terrestrial energy farming. Irrigation and treatment of biomass resources requires access to water supplies. An assessment of water requirements and availability is required for federal support of all nonnuclear energy projects [167]. The large amounts that would be needed for mid-term programs can pose a significant barrier, especially in the arid West where open land might be more readily available. 


\subsection{AQUATIC PARMING}

The three types of systems (marine, coastal/brackish, and freshwater) are considered to be long term and possibly high risk [168]. The technology is in the early research and development stages; legal and environmental considerations will be only briefly noted.

The system presently offering the greatest promise is coastal and/or open ocean farming of the giant California kelp. It is probable that farms greater than $100 \mathrm{mi}^{2}$ will be needed for economic feasibility. Despite the undeveloped state of the technologies involved, the potential for growth of a renewable resource in very large areas without water or land constraints has made kelp farming an attractive potential energy source [169].

One major legal area involving ocean farming is that of international/federal/state jurisdiction. Given the potential size of energy farms, sovereignty conflicts over siting and ocean activities could arise [170]. A second consideration would be that exclusive use of a particular area should not have a negative effect on other uses [171]. Particularly in the high seas, an ocean farm would be subject to other well-established uses such as fishing, navigation, mineral exploration, military uses, and other energy technologies. Two previously established exclusive uses: (1) military-nuclear weapons testing, and (2) fishing fixed lobster and crab pots, have been analogized to mariculture in support of its establishment [172]. 


\section{SECTION 6.0}

\section{CONCLUSIONS}

Biomass is a renewable source of fuel with as yet undetermined potential to add to the nation's and the world's energy supply. It presents many new challenges to environmental, legal, and social policy makers.

Biomass is the only solar technology with significant potential for the production of liquid and gaseous fuels that can replace petroleum products. Biomass technologies could utilize many of the centralized operations and transportation systems already in existence. With minor modifications, existing conventional power plants could convert to wood, DBF, or in the future, biomass-derived oils and gases. Adjustments in regulatory schemes would have to be made to allow consideration of the costs of producing the resource and other unique characteristics of biomass.

Near-term biomass technologies are a limited but significant potential for energy input. The utilization of MSW should be encouraged through extension of the policies of RCRA, perhaps in the form of stronger federal procurement policies for primary products and by-products, and other federal financial support for elements of the private sector that move into the resource recovery field. Use of animal manures to generate methane should be encouraged through financial support and such associations as farmer cooperatives. Through water quality control regulations, use of manures as energy sources could be tied to implementation of improved waste handling techniques. Present internal economic incentives for paper and pulp industry use of forestry residues have already worked to make the residues a major energy source. Incentives in the form of tax benefits for the industry could be used to encourge greater use. This type of internal, on-site biomass use could have significant impact on total energy use by removing the demands of certain industrial segments, while avoiding the major transportation problems involved with biomass. Utilization of crop residues by fermentation into ethanol should proceed cautiously until questions concerning effects on soil depletion are resolved.

The lack of an assured supply of biomass resource could be a major barrier. With MSW, this problem can be handled through long-term contracts with municipalities. With specially grown materials or residues, however, the considerations are different. Possible variations in production, poor yield years, and disease effects could make producers reluctant to risk commitment unless the buyer were willing to contract on an output basis. This could be risky to the power producer; a drop in supply could create a drop in power. This should be considered in the regulatory process, and the utilities' policies could be examined on the basis of their reasonable attempts to secure an assured supply. With terrestrial energy farming, there is justified concern over the possible ecological results of high-intensity, high-energy input monoculture. The potential for devastation of a crop by disease is greater with monoculture; a balanced approach to energy farming on a limited scale with an attempt to diversify the crop composition could increase reliability of the crop.

Our past large-scale energy resources have mostly been fossil fuels that presented technological and ecological problems associated with extraction of the resources. Direct and indirect solar energy already exist in the form of wind or thermal energy in the ocean's waters. Biomass, on the other hand, must be produced if it is to become a significant source of energy in the United States. Extensive terrestrial energy farming would necessitate major land-use changes. Under present public and private land-use 
controls, public lands would be unavailable for use, and suggestions for changes in management of public lands are ill-advised in light of competing uses for those lands and environmental concerns. The "marginal" lands of ten targeted for energy farming are unused because they have poor farming potential. Making these lands productive raises serious questions of total energy balance; equipment, fertilizer, and water requirements for such farming could be too expensive.

Existing agricultural land use and price-support prices could be used to develop energy farming on a limited basis. The USDA, should have more research, development, and policy-making authority. Energy farming should be examined as a part of the existing agricultural system with a commitment to avoid placing energy crops in competition for land with food and fiber crops. Energy crops could be targeted to replace an existing crop with a strong economic base but little social value to the country (e.g., tobacco).

Ocean farming is a long-range possibility for the production of biomass. It has the potential for escaping many of the environmental concerns posed by near- and mid-term technologies. If ocean farming becomes commercially feasible, its international implications for sea use will have to be addressed.

Biomass can make a significant contribution as part of our national energy program. Resources, markets, and conversion technologies are available to render biomass commercially feasible. Environmental limitations are present, but if they are recognized and addressed, they need not dampen an optimistic approach to biomass use. 


\section{SECTION 7.0}

\section{REPERENCES}

1. 42 U.S.C. $\$ 5551$ et seq.

2. 42 U.S.C. $\$ 5552$ Definitions: (1) The term "solar energy" means energy which has recently originated in the sun, including direct and indirect solar radiation and intermediate solar energy forms such as wind, sea thermal gradients, products of photosynthetic processes, organic wastes and others.

3. DOE, Distributed Energy Systems in California's Future, Interim Report, $\mathrm{HCP} / \mathrm{P} 7405-03$, May 1978 (Avail. NTIS).

4. For detailed discussions of biomass operations see: Roller, W.-L. et al., Grown Organic Matter as a Fuel Raw Material Resource, Ohio Agricultural Research and Development Center, NASA CR-2608, 1975. Inman, R. E. et al., Silvicultural Biomass Farms, Vols. I- MITRE Technical Report No. 7347, ERDA, 1977. Leese, T. M., The Conversion of Ocean Farm Kelp to Methane and Other Products in Symposium Papers: Clean Fuels from Biomass, pp. 253-266, Institute of Gas Technology, January 1976. Fraser, M. D. et al., Design, Operation and Economics of the Energy Plantation, in Symposium Papers: Clean Fuels from Biomass, pp. 371-395, Institute of Gas Technology, January 1976.

5. 1 quad $=10^{15}$ Btu (British thermal units).

6. SERI, Review Draft, 1978 Annual Review.

7. Pimentel, D. et al., "Biological Solar Energy Conversion and U.S. Energy Policy," 28 Bioscience, 376-382, June 1978.

8. Id., p. 376 .

9. Total U.S. energy consumption is estimated at 75 quads.

10. For example, the Hilo Coast Processing Company, Pepeekea, HI, supplies electricity to the Hawaiian Electric Light Company (see Bio-Energy Directory, p. 94). The Oahu Sugar Company, Ltd., supplies $75 \%$ of its own annual electricity needs through the burning of bagasse (see Bio-Energy Directory, p. 95).

11. EOP, The National Energy Plan, Executive Office of the President, Energy Policy and Planning, Washington, D.C., 1977.

12. Flaim, S. J. et al., Economic Feasibility and Market Readiness of Eight Solar Technologies, V, Biomass, Interim Draft Report, Solar Energy Research Institute, Golden, CO: June 1978. For further information, the reader is referred to Pimentel, D. et al., Biomass Energy Conversion, Department of Entomology and Section of Ecology and Systematics, Cornell University, Report 78-1, May 1978. (The paper cited in note 6, supra, is an abbreviated version of this report.) For a compilation of various research projects and operational facilities, the reader is referred to: Bio-Energy Council, Bio-Energy Directory, Washington, D.C., June 1978. 
13. DOE, Fuels from Biomass: Multiyear Program Plan, Draft, April 1978.

14. For example, Operational: The Eugene, Oregon, Water and Electric Board operates a 33.8 megawatt capacity steam/electric plant which is fueled by surplus mill residues (see Bio-Energy Directory, note 16, p. 112).

15. Reed, T.; Bryant, B. Densified Biomass: A New Form of Solid Fuel. Solar Energy Research Institute, Golden, CO: July 1978.

16. Witwer et al., "A Comparative Evaluation of Solar Alternatives: Implications for Federal RD\&D." Vol. II., VII, Biomass, Stanford Research Institute, Project 6375, January 1978, p. VII-6.

17. See several projects in the Bio-Energy Directory, supra nnte 12.

18. Fuels from Biomass, Solar Program Assessment: Environmental Factors, ERDA 77-47/7, March 1977, p. 33.

19. See note 6 .

20. Methane is the major component of natural gas.

21. A large-scale demonstration facility built under a U.S. Department of Energy contract is presently in the start-up phase in Pompano Beach, FL. Organic solid wastes and municipal sewage are among the materials to be tested in the 100 ton/day facility (see Bio-Energy Directory, p. 36).

22. For example, two large digesters are supplied by the manure from a 110,000 -head feedlot in Oklahoma. This is the Calorific Resource Anaerobic Process, operated by Thermonetics, Inc., Oklahoma City, OK: (personal communication with Ron James, July 1978). Several long-term research prnjests have heen rarrier nut hy W. J. Jewell at Cornell University utilizing manure from Cornell's teaching and research dairy. See, Jewell, W. J. et al., Anaerobic Fermentation of Agricultural Residue: Potential for Improvement and Implementation, Final Report to U.S. Department of Energy, February 1978, p. 37.

23. For example, the Palos Verdes Sanitary Landfill, Rolling Hills Estates, CA, operated by Keserve Synthetic liuels, Inc., Signal Hill, CA: (personal- communication and Bio-Energy Directory, p. 67).

24. See note 13.

25. See note 17 . 'l'he mixture resulting from the addition of $10 \%$ to $25 \%$ ethyl alcohol to gasoline is called "gasohol" and is currently being test-marketed in the Midwest.

26. See note 16 , p. VII-9.

27. DOE, Biomass Energy Program: Multiyear Program Plan, Draft, January 1979.

28. Id. Conversion of farm residues into ethanol may be an exception to the generalization of biomass fitting into existing business practices. 
29. See Taubenfield, R. F.; Taubenfield, H. J. "Wind Energy: Legal Issues and Legal Barriers." 31 Southwestern Law Review. 1053-1093, Winter 1977. Mayo, L. H. et al., Legal-Institutional Implications of Wind Energy Conversion Systems (WECS). Final Report, NSF/RANN - 770204, September 1977. Knight, G. H. et al., eds., Ocean Thermal Energy Conversion: Legal, Political and Institutional Aspects. American Society of International Law, Lexington Books, D. C. Heath and Co., Lexington, MA: 1977. Environmental Law Institute, Legal Barriers to Solar Heating and Cooling of Buildings. Department of Energy Contract No. EX-76-C01-2528, March 1978; Warren, Michael. Problems in the Administration of State Solar Legislation. Golden, CO: SERI/TR-62-266, July 1979. (Avail. NTIS); Nanda, Ved P. Selected Legal and Institutional Issues Related to Ocean Thermal Energy Conversion (OTEC) Development. Golden, CO: SERI/TR-62-204, June 1979; Coit, Lynde. Wind Energy: Legal Issues and Institutional Barriers. Golden, CO: SERI/TR-62-241, June 1979; Green, Michael. Licensing Arrangements and the Development of the Solar Energy Industry. Golden, CO: SERI/TR-62-260, June 1979 (Avail. NTIS); Laitos, Jan; Feurestein, Randall J. Regulated Utilities and Solar Energy: A Legal-Economic Analysis of the Major Issues Affecting the Solar Commercialization Effort. Golden, CO: SERI/TR-62-255, June 1979; Gross, Jill. Impact of the Antitrust Law on the Commercialization of Solar Heating and Cooling. Golden, Colorado, SERI/TR-62-272 (Avail. NTIS); Laitos and Feuerstein, "May Regulated Utilities Monopolize the Sun." Denver Law Journal, Volume 56, 1979.

30. 42 U.S. $\dot{C} . \$ 5901$ et seq.

31. 42 U.S.C. $\$ 5552$ et seq.

32. 42 U.S.C. $\$ 5555$.

33. See note 27 .

34. İd.

35. The Agricultural Research, Extension and Teaching Act of 1977, 7 U.S.C. 3101 et seq.; Subchapter VII, Solar Energy Research and Development 3241--Authorizes USDA to let competitive grants relating to (2) uses of biomass derived from solar energy, including farm and forest products, by-products, and residues as substitutes for nonrenewable fuels and petrochemicals.

36. See note 18 , pp. 21,24 .

37. Personal communication with John Erickson, Forest Service-USDA and member of Biomass Subcommittee, USDA-DOE Steering Committee, Washington, D.C., 16 June 78.

38. 42 U.S.C. $\$ 6901$ et seg.

39. Generally see Kovacs, W. L.; Klucsik, J. F. "The New Federal Role in Solid Waste Management: The Resource Conservation and Recovery Act of 1976." 3 Columbià J. Env. L. 205-261, 1977.

40. White House, "The President's Message On Solar Energy," 20 June 79. 
41. 1 Solar Law Reporter 266 (1979).

42. Time, 11 June 79 , p. 75.

43. See generally U.S. Dept. of Commerce, Biomass Energy Success Stories, A Portfolio Illustrating Current Economic Uses of Renewable Biomass Energy, March 1978.

44. Ibid. at 21. The mill is owned by the Russell Corporation of Alexander City, AL.

45. Dunwoody, J. E. "Resolving the Environmental Issues in Developing Fuels from Biomass," in Proceedings of Environmental Aspects of Nonconventional Energy Resources-II [hereinafter cited Nonconventional Energy Proceedings], 26-29 Sept 78.

46. See Forest Service-USDA, The Feasibility of Utilizing Forest Residues for Energy and Chemicals. NSF/RANN; NTIS-PB-258-630, March 1976.

47. See Benemann, J.R., Bioconversion, An Assessment, Electric Power Research Institute Draft, December 1977, p. 32.

48. See note 45 .

49. Garabedia, H. T.; Sanborn, C. R. "Environmental Aspects of Wood Fuel," in Nonconventional Energy Proceedings, see note 45 supra.

50. See note 45 .

51. Ibid.

52. DUE, Fucle from Biomaes Environment Development plan (EDP) 1877, March 1278.

53. Clawson, M., Forests for Whom and for What? Resources for the Future, Johns Hopkins Univ. Press, Baltimore, MD: 1975, p. 126.

54. See note 52, p. 47.

55. Natural Kesources Defense Council, Land-Use Controls in the United States. 'I'he Dial Press, New York, NY; 1977, p. 230. See also the Federal Land Policy and Management Act of 1976, Pul. 94-579, 90 Stat. 2744 and the Forest and Rangeland Renewable Resource Planning Act of 1974, both of which require extensive landuse planning decisions for federal land.

56. 33 U.S.C. $\$ 1251$ et seg.

57. See note 55, p. 230 .

58. 16 U.S.C. $\$ 551$ et seq.

59. 522 F.2d 945 (4th Cir. 1975).

60. 16 U.S.C. $\$ 1600$ et seq. 
61. 42 U.S.C. $\$ 1600$ et seq.

62. This was a test applied to clear-cutting in West Virginia (see note 88). If clearcutting could be shown to be silviculturally sound, the Court indicated that such evidence should be presented to Congress.

63. See note 45 .

64. See note 49 .

65. See note 42 and accompanying text.

66. See note 45 at $3-11$.

67. Jewel et al., Bioconversion of Agricultural Wastes for Pollution Control and Energy Conservation. ERDA, NSF/RANN and AERT 741222A01, NTIS-TID-27164, September 1976.

68. Ibid., p.40.

69. See note 22 .

70. Bio-Energy Directory, p. 35 .

71. California Energy Commission, Program Plan: New Resources and Technologies. January 1978, p. 29.

72. "The nearly two billion tons of animal waste produced annually on American farms are estimated to have a pollution potential equal to that of the domestic sewage of 1.9 billion people." See Hines, N. W., "Agriculture: The Unseen Foe in the War on Pollution." 55 Cornell L. Rev. 740-760, 1970, note 5.

73. See note 72 where Hines characterizes some accumulated wastes as "manure mountains rising around feedlots" (n. 12).

74. 38 Fed. Reg. 128 (1973). See note, "How Now Brown Cow: Regulation of Feedlot Pollution in Wisconsin." 3 Env. Affairs 760 (1977).

75. Id. at 78. See Roller, note 4 and note 6 .

76. Jewell, W. J. et al., "Anaerobic Fermentation of Agricultural Residue: Potential for Improvement and Implementation." Chapter IX, Social Considerations of Methane Production on Dairy Farms. DOE Grant No. EY-76-S-02-2981, February 1978.

77. Midwest Research Institute, Technology Assessment of Integration of the HogPork Industry. No. NSF-C 850, July 1977, p. 52 .

78. See note 77, p. 110 .

79. See note 76 . 
80. Solid residuals also have to be disposed of and pollutants will result from clean up of large-scale production of digester gas. Residuals can be dried and spread by methods which minimize run-off water pollution. Treatment of pollutants from the clean up of the gas produced has not been addressed.. See note 45 .

81. Feasibility determination of anaerobic fermentation to recover methane, protein, and plant nutrients from agricultural residues, DOE/USDA funded at Clay Center, Nebraska (see Bio-Energy Directory, p. 46).

82. Research is just beginning in the Department of Civil Engineering, Iowa State University, on residuals from hog manure digestion. Personal communication, E. Dunwoody, sec note 188.

83. Federal Register, 14 Jan 72.

84. MRI, see note 112, p. 152 .

85. Id.

86. Schooley, F. A.; Alich J. et al., An Evaluation of the Use of Agricultural Residues as an Energy Feedstock-A Ten Site Analysis. Vol. I and II, SRI, Menlo Park, CA: July 1977.

87. Farmers have strong opinions both for and against removal. The Soil Conservation Service (SCS) system of guidelines, soil conservation districts, and local agents is well established and has as its major goal to preserve the soil quality of cultivated lands. There is concern within the SCS about the possibility of such residues becoming a valuable commodity, influencing some farmers to remove more than is environmentally sound. Personal communication, Darwyn Briggs, Environmental Services Division, SCS-Washington, D.C., June 1978.

88. See nòte $\mathbf{5 2 .}$

89. See Roller, note 4 .

90. Pimentel, D. et al., "Land Degradation: Effects on Food and Energy Sources," 194, Science, 149-155, 8 Oct 76.

91. See Lipinsky, E. S. Fuels from Sugar Crops, Second Quarterly Report for the U.S. DOE Battelle Columbus Laboratories, 1977.

92. Kujala, P.; Jockman, E. A. "Factors Affecting the Economics of Stillage Treatment in Brazil," International Seminar on the Treatment of Vinhoto, Rio de Janeiro 1976.

93. See note 45 at $3-13$.

94. Time, 11 June 79, p. 75.

95. Freeman H. M.; Olexsey, R. A. "Air Emissions from Waste to Energy System," Nonconventional Energy Proceedings, p. 18-3.

96. 42 U.S.C. 3251 et seq., transferred to 42 U.S.C. 6901-6987. 
97. Much of this discussion is taken from Kovacs and Klucsik (see note 39).

98. 42 U.S.C. 6901.

99. Id. at subsec. (b).

100. Kovacs and Klucsik (see note 39, p. 215 ).

101. 42 U.S.C. $\$ 6901$

(d) Energy - The Congress finds with respect to energy, that-(1) solid waste represents a potential source of solid fuel, oil, or gas that can be converted to energy; (2) the need exists to develop alternative energy sources for public and private consumption in order to reduce our dependence on such sources as petroleum products, natural gas, nuclear and hydroelectric generation; and (3) technology exists to produce usable energy from solid waste.

102. 42 U.S.C. $\$ 6903(22)$.

103. For example, Westchester County, NY, included two energy recovery facilities in its solid-waste disposal system. One would burn refuse and generate steam and electricity for a medical center and sell the surplus power. The other would produce powdered refuse derived fuel (RDF) which could be used in boilders with oil or coal. From: "Delbello Gives Cost of Solid Waste Plan," New York Times, Thursday, 5 Jan 78.

104. 42 U.S.C. $\$ 6961$.

105. For example, the North Shore Resources-From-Refuse Facility at Saugus, MA, has a capacity of 1,200 tons/day. In early 1978, the plant was processing approximately 984 tons/day, an increase from 736 (34\% increase) at start-up in early 1977. The company attributes its below capacity operation to slow enforcement of existing legislation regarding the environmental quality of dumps, resulting in availability of less costly though environmentally polluting landfill sites. Effective efforts to eliminate such dumping should improve the economic competitiveness of the Saugus plant. From: Wheelabrator-Frye, Inc., The Boston North Shore Resources-From-Refuse Facility (Pamphlet), 1978.

106. Litigation is currently pending in Akron, Ohio, between the prospective bond issuing concern and the affected municipalities over the power to mandate such delivery. Personal communication: Steve Bergerson, Counsel, Waste Management, Inc., Oak Brook, IL.

107. RCRA 42 U.S.C. 6903(11). 'The term 'long-term contract' means, when used in relation to solid waste supply, a contract of sufficient duration to assure the viability of a resource recovery facility (to the extent that such viability depends upon solid waste supply)."

108. The Saugus facility (RESCO) has long-term contracts with 11 communities for 206,000 tons of refuse per year. The facility also accepts and processes both municipal and commercial solid waste on a spot or short-term contract basis. Three districts of the City of Boston are currently under a three-year contract for 40,000 tons/yeall. See note 51 . 
109. 42 U.S.C. $\$ 6943$.

110. Johnson, K. E., "State Embargo of Solid Waste: Impermissible Isolation or Rational Solution to a Pressing Problem?" 82 Dick. L. Rev. 325-350, Winter 1978.

111. E.g., N.J. Stat. Ann. 13.

112. Philadelphia v. New Jersey, 437 U.S. 617 (1978)

113. The N.J. Supreme Court suggested that the N.J. Commission of Environmental Protection could decide that some MSW could be introduced, even with the statute in effect, if such introduction could be carried out without endangering the public health, safety, and welfare. See note 13, p. 22 and Forest Service-USDA, The Feasibility of Utilizing Forest Residues for Energy and Chemicals, NSF/RA $\overline{N N ;}$ NTIS-PB-258-630, March 1976, p. 10.

114. Note 95; Fischer, W. H. "Some Environmental Impacts of Resource Recovery Systems," Nonconventional Energy Proceedings, p. 20-3.

115. See note 95 at $18-5$.

116. See Fischer, note 114.

117. Id.

118. See Guandolo, J., Transportation Law, 2nd Ed., Wm. C. Brown, Dubuque, pp. 58-59.

119. 49 U.S.C. $\$ 1(6)$.

120. See note 118 , pp. $403-404-$ "The primary purpose of a freight classification is to assign each article, or group of articles, to a class according to well-known classification principles or elements which recognize distinctions from a transportation standpoint, along fairly broad lines, to meet the needs of commerce."

121. Guandolo (n. 119 , p. 411 ) lists: (1) shipping $w t / \mathrm{ft}^{3}$, (2) liability to damage, (3) liability to damage other commodities, (4) perishability, (5) liability to spontaneous combustion or explosion, (6) susceptibility to theft, (7) value/lb in comparison with other articles, (8) ease or difficulty in loading or unloading, (9) stowability, (10) excessive weight, (11) excessive length, (12) care or attention necessary in loading and transporting, (13) trade conditions, (14) value of service, (15) competition with other' com modities transported.

122. See note 118 , pp. $404-405$.

123. United States v. Students Challenging Regulatory Agency Procedures (SCRAP)(I), 412 U.S. 669 (1973). Aberdeen and Rockfish R.R. v. SCRAP (SCRAP[II), 422 U.S. 289 (1975).

124. See Rodgers, W. H., Environmental Law, West Publishing Co., St. Paul, MN: 1977, p. 652 . 
125. See, e.g., Interstate Commerce Commission v. KSI Farm Lines Co-Op, Inc., $407 \mathrm{~F}$ Supp. 145 (E.D. Wis., 1976).

126. Section 6951 charges the Secretary of Commerce to encourage greater commercialization of proven resource recovery technology by providing accurate specifications for materials, stimulating development of markets, promoting proven technology, and providing a forum for exchange of technical and economic data, and $\$ 6952$ provides for the development of specifications for secondary materials through the National Bureau of Standards.

127. 42 U.S.C. $\$ 6962$.

128. See Rodgers note 124, p. 648.

129. See note 13, p. 34 .

130. See, e.g., note 6 .

131. Solar Energy Intelligence Reporter (SEIR), 19 June 78, p. 181.

132. SEIR, 19 June 78, p. 183.

133. See note 131 .

134. SEIR, 15 May 78, p. 143.

135. SEIR, 5 June 78, p. 165.

136. Gasohol blenders were paying $\$ 1.30 /$ gallon for the ethyl alcohol, adding about $\$ 0.13 /$ gallon to the cost which was averaging $\$ 0.72 /$ gallon in Ilinois. SEIR, see note 135 .

137. SEIR; 19 June 78, p. 181 .

138. See comments by Martin Robbins, Director, Colorado Energy Research Institute, Rocky Mountain News, Denver, CO: 6 Aug 78, p. 8.

139. This is measured by $\mathrm{Btu} / \mathrm{ft}^{3}$ of gas. Since gas produced from anaerobic digestion is high in $\mathrm{CO}_{2}$, it usually would have to be upgraded for introduction into a pipeline. For example, $1,000 \mathrm{Btu} / \mathrm{ft}^{3}$ is the usual requirement (personal communication with representative of Southern California Gas Co., July, 1978), as compared to the only $750 \mathrm{Btu} / \mathrm{ft}^{3}$ level (even after partial upgrading) of gas being recovered from a sanitary landfill at Mt. View, CA (personal communication with Myron Jones, Pacific Gas and Electric).

140. See note 22 .

141. Natural Gas Pipeline Company of America, FPC Docket No. CP 75- 147, Opinion No. 763, 24 May 76. This ruling is consistent with the rulings in Algonquin SNG, Inc., FPC Docket Nos. CP77- 35 (Naphtha SNG not "natural") and El Paso Natural Gas Company, FPC Docket No. CP73-131 (coal SNG not "natural").

142. See Public Utilities Fortnightly, August 12, 1976, pp. 56-57. 
143. Personal communications: Jim Semis, Thermonetics, Okalahoma City, OK: July 1978, and Gene Hasenberg, Natural Gas Pipeline Company of America, Chicago, IL: July 1978.

144. SRI, see note 16 , p. VII-15.

145. Personal communication with Don Kaplan, Kaplan Industries, Bartow, FL: operator of envirumienlal feedlut with anaerobic digcstion eystom funded by DOE.

146. Utilities in ELI, see note 29, pp. 86-118.

147. See Mayo, note 29, p. 128, und SEIR, 22 Nov 76, p. 131, and 6 Dec 76, p. 189.

148. The Saugus, MA facility (see note 98) sells steam only to a General Electric jet engine and steam turbine plant just across the Saugus Kiver in Lynn, MA.

149. The methane recovered from the Palos Verdes sanitury landfill (see note 26) is sold for use by the municipal utility.

150. See note 23 .

151. Within the meaning of 16 U.S.C. $\$ 824(e)$.

152. 16 U.S.C. $\$ 824 a(b)$ authorizes the FPC to "direct a public utility . . . to establish physical connection of its transmision facilities with the facilities of one or more persons engaged in the transmission or sale of electric energy, to sell energy to or exchange energy with such persons."

153. Under 16 U.S.C. $\$ 824(d)(a)$ concerning just and reasonable rates.

154. A "cogeneration facility" is defined as a "facility which produces-electric energy, and ... . other forms of useful energy (such as heat) which are used for induslrial, commereial, hcating or cooling purposes." Title II, $\$ 2.01$ of the Public Utility Regulatory Policies Act of 1978, Pub. L. No. 95-619, 92 Stat. 3117 (1978). FERC regulations governing cogenerating facilities are found in $\$ 210$ of Title II of PURPA.

155. Note 37 , pp. 1-5.

156. Id., p. 5.

157. See text accompanying notes 46-66.

158. See text accompanying notes 86-93.

159. See note 45 .

160. The plantation is at the Savannah River Plant, Aiken, SC.

161. See note 54, p. 53 . 
162. For example, the California Energy Commission plans during 1978/79 to identify candidate energy farm locations which could also serve as recreational areas near a city (see note 87 , p. 28 ).

163. See note 4, MITRE, Vol. III, Land Suitability and Availability. p. S-2. The MITRE study was an extensive survey of mostly private land availability for energy farming. The minimum standards set for inclusion of land were (1) at least 25 " of precipitation annually, (2) arable land, and (3) a slope less than or equal to $30 \%$ $\left(17^{\circ}\right)$. Scenarios two and three, as developed by MITRE, represent 270 and 320 million acres, respectively. If $10 \%$ of the land in each scenario actually became available, scenario two would yield four to seven quads annually and scenario three, four to eight quads annually.

164. Id., pp. 5-7.

165. Id., p. 45.

166. See note 16, p. VII-15.

167. Federal Nonnuclear Energy R\&D Act, 42 U.S.C. 5912.

168. See note 13 .

169. See note 102, p. 93. The California Energy Commission plans in 1978/79. to: "Choose first Northern California ports as landing points for product from kelp farms; analyze on-shore needs for fuel conversion and transportation facilities; provide California input to development of actual kelp farms." (See note 104, p. 28.)

170. Washom, B., Spatial and Emerging Use Conflicts of Ocean Space in OTEC. (See note 28 ), p. 9 l.

171. Kane, T., Aquaculture and the Law. Sea Grant Technical Bulletin No. 2, November 1970 , p. 65 .

172. See note 171 , pp. $62-63$. 


\begin{tabular}{|c|c|c|c|}
\hline $\begin{array}{l}\text { Document Control } \\
\text { Page }\end{array}$ & $\begin{array}{r}\text { 1. SERI Report No. } \\
\text { TR-62-264. }\end{array}$ & 2. NTIS Accession No. & 3. Recipient's Accession No. \\
\hline \multirow{2}{*}{\multicolumn{3}{|c|}{$\begin{array}{l}\text { 4. Title and Subtitle } \\
\text { Legal Considerations in the Development and } \\
\text { Implementation of Biomass Energy Technologies }\end{array}$}} & $\begin{array}{l}\text { 5. Publication Date } \\
\text { September } 1979\end{array}$ \\
\hline & & & 6. \\
\hline \multicolumn{3}{|l|}{ 7. Author(s) } & 8. Performing Organization Rept. No. \\
\hline \multicolumn{3}{|c|}{$\begin{array}{l}\text { 9. Performing Organization Name and Address } \\
\text { Jolar Energy Research Insti tute/DOE } \\
\text { 1536 Cole Boulevard } \\
\text { Golden, CO } 80401\end{array}$} & $\begin{array}{l}\text { 10. Project/Task/Work Unit No. } \\
\text { Task \#6223.20 } \\
\text { 11. Contract (C) or Grant (G) No. } \\
\text { (C) } \\
\text { (G) }\end{array}$ \\
\hline \multirow{2}{*}{\multicolumn{3}{|c|}{ 12. Sponsoring Organization Name and Address }} & $\begin{array}{l}\text { 73. Type of Heport \& Period Covered } \\
\text { Technical Report }\end{array}$ \\
\hline & & & i4. \\
\hline
\end{tabular}

15. Supplementary Notes

16. Abstract (Limit: 200 words) The photosynthetic energy stored in plant and organic waste materials in the United States amounts to approximately $40 \%$ of the nation's total energy consumption. Conversion of this energy to usable power sources is a complex process, involving many possible materials, conversion technologies, and energy products. Near-term biomass technologies are predominantly based on traditional fuel use and have the advantage over other solar technologies of fitling into existing tax and business practices. However, no other solar technology has the potential for such large environmental impacts. Unlike the conversion of sun, wind, and ocean thermal energy, the conversion of the biomass energy source, in the form of biomass residues and wastes, can create problems. Environmental impacts may be significant, and legal responses to these impacts are a key determinant to the widespread adoption of biomass technologies. This paper focuses on the major legal areas which will impact on biomass energy conversion. These include (1) the effect of existing state and federal legislation, (2) the role of regulatory agencies in the development of biomass energy, (3) governmental incentives to biomass development, and (4) legal issues surrounding the functioning of the technologies themselves. Emphasis is placed on the near-term technologies whose environmental impacts and institutional limitations are more readily identified. If biomass energy is to begin to achieve its apparently great potential. these questions must receive immediate at tention.

17. Document Analysis

a. Descriptors Biomass; Biomass Plantations; Bioconversion; Legal Aspects; State Government; National Government; Wastes; Env1ronmental Impacts; Ecunumics;

- Wood; Wood Products Industry; Manures; Solid Wastes; Crops; Residues

b. IdentifiersiOpen-Ended Terms

c. UC Categories

61

18. Availability Statement

NTIS (National Technical Information Service)

5285 Port Royal Road

Springfield, VA 22161 19. No. of Pages

46

20. Price

$\$ 4.50$ 